\title{
David Bromell
}

\section{Why (Not) Political Philosophy?}

Introduction

Why political philosophy? Why do I read it, teach it and

encourage others to engage in it? Simply, because I am driven

to it by my practice as a public servant. I have spent a great

deal of my working life in meetings where we discuss, decide

or make judgements about public policy. I notice how often

we express or imply 'big ideas' in our discussions with one

another, but mostly in an unthinking (even unconscious) way.

So we skate over confusions and contradictions in our own

and others' thought and too frequently talk past each other.
Take, for example, current debate about physician-assisted suicide and active, voluntary euthanasia. Complex ideas are at play about liberty, the autonomy of the individual, volition and consent, human dignity, the 'sacredness' of life, death and dying, medical ethics and the state's duty of care to vulnerable individuals.
When we stumble over big ideas or trip over unexamined assumptions, I want to slow down and think, to take time to sort out my own thinking until I can see clearly what is at stake in an argument, where our real differences lie, and hopefully shed some light on this for others too.
David Bromell is a Principal Advisor in the Strategic Policy Team at Environment Canterbury and a Senior Associate of the Institute for Governance and Policy Studies. Since 2012 he has co-taught, with Professor Jonathan Boston, a course on politics, philosophy and public policy (GOVT 539) in the Master of Public Policy programme in the School of Government at Victoria University of Wellington. In 2016 he is a Mercator Research Fellow in the NRW School of Governance, University of DuisburgEssen, Germany.
The difficulty is compounded because none of us comes to public policy debate with a 'blank slate'. Like the vast majority of the people I deal with in public life, I want to make a difference. That already implies value judgements about states of affairs, desired outcomes, preferred means to get from here to there and responsibilities to make it happen. Those are matters on which I not only observe conflict between people (and political parties), but also experience conflict within myself - second thoughts; my own divided opinions; discrepancies between what I think I think, and the courses of action I end up pursuing in fact. It is this experience of conflict, confusion, inconsistencies, incompleteness and contradiction that drives me to critical reflection in general, and to political philosophy in particular.

So what exactly is political philosophy, and how do we do it?

\section{Definition of terms}

Before we can address the question, 'What is political philosophy?' we need to tackle a prior question, 'What is philosophy?'

Sellars suggested that 'The aim of philosophy, abstractly formulated, is to 
understand how things in the broadest possible sense of the term hang together in the broadest possible sense of the term' (Sellars, 1963, p.1). Philosophy tries to think and speak clearly about the nature, goals and possibilities of our various ways of dealing with self, others and the allencompassing whole ('world') in which we find ourselves. As Larmore puts it:

Its ambition is therefore to be maximally reflective: philosophy differs from other kinds of inquiry in that it aims to render explicit and critically evaluate the implicit assumptions on which they, as well as our experience as a whole, happen to rely. (Larmore, 2012, pp.5-6)

In other words, when we 'do philosophy' (i.e., think philosophically) we take a step back from being, feeling, knowing, thinking, deciding, speaking and acting, to reflect in a conscious, reasoning way on what we express and imply more or less unconsciously when we lead our lives in the company of others in a particular place and time, influenced by this or that culture, tradition and habit of thought and life.

Doing philosophy is like using a camera in manual mode instead of using its automatic ('point and shoot') settings. ${ }^{1}$ When I want to capture a fleeting moment quickly and efficiently in more or less standard lighting conditions, 'point and shoot' generally does a good job. But arresting photos - photos that make you want to stop and look twice - require intention, thought, knowledge, training and practised skill. I need to 'step back' from the scene or object I wish to photograph and think in a deliberate way about composition, perspective, lighting, depth of field, ISO setting, aperture setting and shutter speed, then use manual mode to create the image. Manual mode is more flexible than 'point and shoot', but it is not a quick or 'efficient' process. It takes time, thought and energy (and patience on the part of a travelling companion). Using manual mode is not something I choose to do every time I use a camera.

Similarly, I do not reflect consciously and critically on every moment of my being, feeling, knowing, thinking, deciding, speaking and acting. That would be an inefficient and paralysing way of leading my life, and exceptionally irritating to those who live and work with me. But there are moments when switching out of automatic mode enables more flexible and creative responses to the challenges and questions life and work throw at us. Standing back and thinking things through helps us discern alternatives and ways forward that create public value (Bromell, 2012), that are more flexible and fit for purpose, better and sometimes even wiser than those we might have opted for in 'point and shoot' mode.
One reason to do political philosophy is to think critically about the ideologies (or belief systems) that guide, enable and constrain - so much of our everyday thinking and deciding. An ideology is a set of doctrines or beliefs about how the world (or some part of it) works which forms the basis of a political, economic or other system. Ideologies are largely assumed and often taken for granted. They provide shortcuts to thinking that help us make sense (in a more or less unreflective way), and guide our decisions and actions. They are like automatic settings on the camera. ${ }^{2}$

\section{Doing philosophy is like using a camera in manual mode instead of using its automatic ('point and shoot') settings.}

So what, then, is 'political philosophy'? 'Politics', and its adjective 'political', refers to institutions, processes, methods and behaviours that govern (i.e., enable organised control over) or influence human social organisation. Politics particularly concerns the allocation, distribution and use of power, resources and status, between individuals, voluntary associations (e.g. families and community groups) and states (non-voluntary associations which include everyone within a given territory and exercise coercive power over them). Political philosophy is thus critical reflection on human political organisation, coercion and the legitimate use of force, and the distribution of power, resources, duties and honours within a society. Political philosophy does this, as Bhikhu Parekh explains, not by pontificating but by:

clarifying issues, analysing the language in which they are framed, exposing specious arguments and offering better ones, examining and criticizing the political principles in terms of which political actors take and defend their decisions, and articulating a historically relevant and possible vision of a good society. (Parekh, 2008, p.7)
Most ideologies are adjectives that have been turned into nouns ending in -ism: capitalism, socialism, liberalism, utilitarianism, libertarianism, egalitarianism, communitarianism, biculturalism, etc. Political philosophy switches the camera to manual mode, and sets out to recover the adjective, and the ideas, behind and between the -isms. As David Miller (1998) puts it:

\begin{abstract}
No political philosopher can break free entirely from the grip of ideology, but political philosophy must involve a more critical scrutiny of the intellectual links that hold ideologies together, and a bringing to light of the unstated assumptions that underpin them.
\end{abstract}

In practice, this characteristically means I am driven to do political philosophy reactively (Cohen, 2011), because I have become frustrated with how things are compared with how I think they ought to be; perplexed about 'the right thing to do'; puzzled about how to resolve arguments and conflict in the public sphere; or because I am having second thoughts about my own perceptions, moral intuitions and judgements. We argue with ourselves, 
and we argue with one another, about 'the right thing to do', how much government is good for us, and just ways of organising our interactions and dependencies on one another. Confusion, and wanting to sort it out, is the impulse to political philosophy (Sandel, 2009, p.28). Or, as Jean-François Lyotard puts it, philosophy springs from lack and desire:

The reality of philosophy results solely from the unreality of reality, so to speak; it results from the lack experienced in reality, it springs from

\section{Distinct but related disciplines}

Moral philosophy, as Robert Nozick argued, sets the background for, and boundaries of, political philosophy:

What persons may and may not do to one another limits what they may do through the apparatus of a state, or do to establish such an apparatus. The moral prohibitions it is permissible to enforce are the source of whatever legitimacy the state's fundamental coercive power has. (Nozick, 1974, p.6)

\section{Above and beyond any choice between focusing on ideal social arrangements and focusing on the choice and design of institutions, the critical issue is the extent to which people can actually lead lives they have reason to value ...}

the way that desire for something else, for another organization of the relations between human beings, a desire that is at work in society, does not manage to free itself from the old social forms. (Lyotard, 2013, p.107)

While political philosophy as critical reflection seeks to think its way from the concrete to the abstract, the particular to the general, unless it remains grounded in and relevant to actual situations and relationships, 'haunted by reality' and the lacks and desires of real people, then it risks leading us back to ideology (ibid., p.106) rather than away from it.

This in turn suggests that the task of political philosophy is unconcluded and unconcludable. The questions confronted by political philosophy are difficult, intellectually as well as practically. While political philosophy cannot hope to resolve disagreements once and for all, it can give shape to our political arguments and bring moral clarity to the choices we confront as citizens (Sandel, 2009, p.19).
In other words, political philosophy reflects on how society should be organised in light of ideas about how individuals should treat each other (Sandel, 2009, p.6). It involves 'deliberations over the principles that frame how we are live to with each other' (James, 2006, p.294).

This understanding of political philosophy is, however, contentious. Larmore (2012) has analysed and commented on two rival conceptions of political philosophy, which reflect disagreement on how moral philosophy and political philosophy are related and how they are to be distinguished.

1. Political philosophy is applied moral philosophy that aims to lay out the purposes (ends) that political association ought to pursue and the principles of an ideal, just or 'wellordered' society.

2. Political philosophy is an autonomous discipline that deals with means, rather than ends; specifically, the social and political institutions that enable us to live together despite our different interests and fundamental disagreements over moral ideals.

According to Larmore, the first approach can be seen in Aristotle (Politics, I.1-3; Nichomachean Ethics, I.2, X.9), and had strong advocates in Isaiah Berlin, John Rawls (1971) and Jerry (G.A.) Cohen (2009, 2011). The second approach can be seen in Weber (Wirtschaft und Gesellschaft, I.1.2., pp.1217) and in Hobbes' opting for law as a 'common standard' rather than ethics (Leviathan, introduction and I.xiii.8), and has been advocated more recently by Bernard Williams (2005) and Raymond Geuss (2008). ${ }^{3}$

The two approaches seem to me to involve an unnecessary and false antinomy. My practice as a public servant drives me to reflect on both ends and means: on the purposes we hope to achieve, and the methods we adopt to achieve them; on institutions, and the character of those who serve in them; on where we might reach reasonable agreement, and how we might create and maintain institutions that enable us to live well with our reasonable disagreements. We see a both/and approach to ends and means in, for example, James Madison's twin observations in The Federalist, no. 51 that:

Justice is the end of government. It is the end of civil society. It ever has been and ever will be pursued until it be obtained, or until liberty be lost in the pursuit. [= ends]

If men were angels, no government would be necessary ... In forming a government which is to be administered by men over men, the great difficulty lies in this: you must first enable the government to control the governed; and in the next place oblige it to control itself. [= means] (Madison, 1787, pp.340, 337)

Above and beyond any choice between focusing on ideal social arrangements and focusing on the choice and design of institutions, the critical issue is the extent to which people can actually lead lives they have reason to value (Sen, 2009, pp.18, 231-47). The fundamental question for political philosophy is, 
therefore, how together we might live, live well and live better, despite our reasonable disagreements about ends, means, the legitimacy of our institutional arrangements and the character of those who serve in them. Ultimate aims, theories of justice and visions of the good society matter; so do institutions, their operation and legitimacy (Waldron, 2013, 1999).

Consequently, the questions I keep returning to when I do political philosophy cluster around both justice and 'the good society' (ends), and government, institutions and public policy making (means).

\section{Justice and 'the good society'}

- Who owes what to whom (other humans, non-human creatures and the physical environment)?

- What is a 'good society', and what do we mean by 'the public interest' and 'the common good'?

- What is 'private' and what is 'public'?

- Which principles might guide how we distribute income and wealth, benefits and burdens, rights and responsibilities, powers and duties, punishments and rewards, offices and honours?

- What do 'equality' and 'a fair go' mean?

- What does 'justice' mean in a globalising world?

\section{Government, institutions and public policy making}

- What is the most desirable (or least undesirable) form of government, and how much government is good for us?

- How might we best design political institutions in order to balance 'me' and 'us', the private and the public, freedom and individual liberty with belonging, community and social responsibility?

- How is a liberal state to deal with diversity, and with both 'reasonable' and 'unreasonable' disagreement ('us' and 'them')?

- When and by whom can coercion legitimately be exercised, and what are the limits to a state's legitimate use of force?
- What should we assume about human nature in policy and politics?

- Which qualities are desirable in elected and appointed officials?

- How should policy making proceed when people disagree on values, objectives and priorities?

The tasks and characteristic preoccupations of political philosophy as outlined above suggest why and how political philosophy is distinct from the related discipline of political science (or political studies). Political science concerns itself with comparative, visions of social relations (Young, 1990, p.226), to 'realistic utopias' that extend what are ordinarily thought to be the limits of political practicability and, in so doing, reconcile us with our political and social condition (Rawls, 1999, pp.11-12). Political philosophy brings ethics back into the centre of politics.

\section{Why not political philosophy?}

Good government does not happen by accident. It happens because men and women commit themselves to public life and public service, to responsibility

\section{Doing political philosophy trains the mind for critical thinking in public life, as a prelude to considered, intentional action.}

empirical analysis and understanding of institutions and institutional choices, often through pragmatic or consequential assessment. Waldron argues that political philosophy pushes beyond political science by engaging in 'certain elements of non-consequential assessment':

Here I have in mind the deeper layers of dignitarian value, for example, that explain why certain processes like democratic decision-making and the rule of law are important quite apart from their outputs and quite apart from their efficiency. We have to consider ways in which various institutional alternatives embody various kinds of respect for the persons upon whom and in whose name our laws and policies are administered - respect for them as persons, as agents, as centers of intelligence, and respect for their dignity as individuals. (Waldron, 2013, p.12)

Political philosophy is normative theory, oriented towards critiquing and changing social arrangements, not merely describing or explaining them. Normative theory draws our attention to alternative with accountability, to the maintenance and renewal of political traditions and political institutions, to action and to reflection. Given the challenges of public life in this place, at this time, how can we not commit at least some of our time and energy to read widely, think deeply and communicate clearly about the ends and means of politics?

Exercising ethical leadership in politics and public service requires us to make transparent, to ourselves and to others, where our interests lie, including the visions, values, ideas, ideals and commitments that drive and sustain us. When we are self-consciously reflective about these things we are less likely to talk past each other, less likely to assume that we mean and want the same things, better able to identify where our real differences lie, and better prepared to engage in robust appraisal of policy options and to articulate a clear value proposition for policy proposals. Doing political philosophy trains the mind for critical thinking in public life, as a prelude to considered, intentional action.

The invitation and encouragement to do political philosophy comes, however, with a note of caution. Doing philosophy requires both curiosity and courage. It 
requires curiosity about why we do this and not that; why we have settled for a particular social, economic or political arrangement; why we feel strongly about $X$ and find idea $Y$ repugnant; what our everyday speech reveals about our underlying assumptions and structures of thought; how jargon has come to infect our thought and speech; why people feel differently and think differently from others; and how we can live differently together without violence.

Doing philosophy also requires courage - courage to think differently, to change your mind. Because, having admitted an idea to thought, having entertained it and let it take root in you, an idea may change your priorities, commitments and way of life. For many, that will be sufficient reason not to do political philosophy. Doing philosophy is for those who relish adventures of ideas, who experience being nudged and tugged by the longing for something more and better than what we already know, and think, and do:

This is why we philosophize: because there is desire, because there is absence in presence, deadness in life; and also because there is our power that is not yet power; and also because there is alienation, the loss of what we thought we had acquired and the gap between the deed and the doing, between the said and the saying; and finally because we cannot evade this: testifying to the presence of the lack with our speech. In truth, how can we not philosophize? (Lyotard, 2013, p.123)
1 Joshua Greene (2013, ch.5) uses this metaphor to describe how the moral brain works. Automatic settings are efficient but inflexible; manual mode is flexible but inefficient. This is one way of elaborating what Daniel Kahneman means by Thinking, Fast and Slow (2011).

2 Although the word 'ideology' was only coined in the 1790s in the context of the French revolution, more or less conscious ideas about 'the good society' and ideal social, economic and political arrangements have been in evidence since at least the 10th century BCE.

3 Jeremy Waldron (2013), following Hume (1742), sketches a similar contrast between focusing political theory on institutions or on the character of those who inhabit them (the virtues).

\section{Acknowledgements}

This article has benefited from discussions with and critical review by Michael Macaulay and Sven Grundmann. The author also thanks Jonathan Boston and an anonymous reviewer for their feedback, and, more widely, all those who have argued with him over the years and obliged him to think, and think again.

\section{References}

Bromell, D. (2012) 'Creating public value in the policy advice role: a reflection from the front line', Policy Quarterly, 8 (4), pp.16-22

Cohen, G. (2009) Rescuing Justice and Equality, Cambridge, Mass: Harvard University Press

Cohen, G. (2011) 'How to do political philosophy', in M. Otsuka (ed.), On the Currency of Egalitarian Justice, and Other Essays in Political Philosophy, pp.225-35, Princeton: Princeton University Press

Geuss, R. (2008) Philosophy and Real Politics, Princeton: Princeton University Press

Greene, J. (2013) Moral Tribes: emotion, reason, and the gap between us and them, London: Atlantic Books

Hume, D. (1742) 'That politics may be reduced to a science', in E. Miller (ed.) (1987), Essays: moral, political, and literary, Library of Economics and Liberty, Part 1, Essay 3, retrieved from http://www. econlib.org/library/LFBooks/Hume/hmMPL3.html

James, P. (2006) Globalism, Nationalism, Tribalism: bringing theory back in, London: Sage

Kahneman, D. (2011) Thinking, Fast and Slow, New York: Farrar, Strauss and Giroux

Larmore, C. (2012) 'What is political philosophy?', Journal of Moral Philosophy, doi 10.1163/174552412X628896

Lyotard, J.-F. (2013) Why Philosophize? (translated by A. Brown), Cambridge: Polity

Madison, J. (1787) Essay no.51, in A. Hamilton, J. Jay and J. Madison, The Federalist: a commentary on the constitution of the United States being a collection of essays written in support of the constitution agreed upon September 17, 1787, by the Federal Convention, sesquicentennial edn, 1937, with introduction by E. Earle, Washington, DC: National Home Library Foundation

Miller, D. (1998) 'Political philosophy', in E. Craig (ed.), Routledge Encyclopedia of Philosophy, London: Routledge, retrieved from http:// www.rep.routledge.com/article/S099

Nozick, R. (1974) Anarchy, State and Utopia, Oxford: Blackwell

Parekh, B. (2008) A New Politics of Identity: political principles for an interdependent world, Basingstoke; New York: Palgrave Macmillan

Rawls, J. (1971) A Theory of Justice, Cambridge, Mass: Belknap Press Rawls, J. (1999) The Law of Peoples; with 'The idea of public reason revisited', Cambridge, Mass: Harvard University Press

Rawls, J. (2001) Justice as Fairness: a restatement, Cambridge, Mass: Belknap Press

Sandel, M. (2009) Justice: what's the right thing to do?, New York: Farrar, Straus and Giroux

Sellars, W. (1963) Science, Perception, and Reality, London: Routledge and Kegan Paul

Sen, A. (2009) The Idea of Justice, Cambridge, Mass: Belknap Press Waldron, J. (1999) Law and Disagreement, Oxford: Clarendon Press Waldron, J. (2013) 'Political political theory: an inaugural lecture', Journal of Political Philosophy, 21 (1), pp.1-23

Williams, B. (2005) In the Beginning Was the Deed: realism and moralism in political argument, edited and with an introduction by G. Hawthorn, Princeton: Princeton University Press

Young, I. (1990) Justice and the Politics of Difference, Princeton: Princeton University Press 